Meta

Journal des traducteurs

Translators' Journal

\title{
Skopos and (Un)certainty: How Functional Translators Deal with Doubt
}

\section{Christiane Nord}

Volume 61, numéro 1, mai 2016

Des zones d'incertitudes en traduction

URI : https://id.erudit.org/iderudit/1036981ar

DOI : https://doi.org/10.7202/1036981ar

Aller au sommaire du numéro

Éditeur(s)

Les Presses de l’Université de Montréal

ISSN

0026-0452 (imprimé)

1492-1421 (numérique)

Découvrir la revue

Citer cet article

Nord, C. (2016). Skopos and (Un)certainty: How Functional Translators Deal with Doubt. Meta, 61(1), 29-41. https://doi.org/10.7202/1036981ar

\section{Résumé de l'article}

La traduction ne connaît pas de règles. La traduction est un processus de prise de décisions, formé d'étapes dont chacune comporte une part d'incertitude. Dans l'article qui suit, j'entends montrer en quoi une procédure descendante peut au moins permettre de réduire cette incertitude dans une certaine mesure. Au sommet se trouve le cahier des charges, qui détermine la nature et la forme de la traduction. Il y a ici un choix binaire à faire entre traduction documentaire, qui met en valeur les aspects pragmatiques du texte source, et traduction instrumentale, qui met en oeuvre une pragmatique nouvelle, en réorganisant par exemple la deixis. L'échelon suivant est celui des normes et conventions culturelles. La décision devient alors plus complexe, car le cahier des charges peut appeler à reproduire certains comportements de la culture-source et parallèlement à en adapter d'autres aux conventions de la culture-cible - et cela qu'il s'agisse de traduction documentaire ou instrumentale. Le troisième échelon fait intervenir la langue. Certes, nous pouvons dans la plupart des cas nous attendre à ce que la traduction s'aligne sur les normes du système formé par la langue-cible. Certains cas peuvent néanmoins nécessiter de reproduire les normes de la langue-source, par exemple pour réaliser une traduction interlinéaire à des fins linguistiques. Les deux derniers niveaux supposent enfin de dissiper ce qui reste de doute, en prenant d'abord en compte les restrictions d'ordre contextuel et, in fine, les éventuelles préférences personnelles du traducteur.
Ce document est protégé par la loi sur le droit d'auteur. L'utilisation des services d'Érudit (y compris la reproduction) est assujettie à sa politique d'utilisation que vous pouvez consulter en ligne.

https://apropos.erudit.org/fr/usagers/politique-dutilisation/ 


\title{
Skopos and (Un)certainty: How Functional Translators Deal with Doubt
}

\author{
CHRISTIANE NORD \\ University of the Free State, Bloemfontein, South Africa \\ cn@christiane-nord.de
}

\section{RÉSUMÉ}

La traduction ne connaît pas de règles. La traduction est un processus de prise de décisions, formé d'étapes dont chacune comporte une part d'incertitude. Dans l'article qui suit, j'entends montrer en quoi une procédure descendante peut au moins permettre de réduire cette incertitude dans une certaine mesure. Au sommet se trouve le cahier des charges, qui détermine la nature et la forme de la traduction. Il y a ici un choix binaire à faire entre traduction documentaire, qui met en valeur les aspects pragmatiques du texte source, et traduction instrumentale, qui met en œuvre une pragmatique nouvelle, en réorganisant par exemple la deixis. L'échelon suivant est celui des normes et conventions culturelles. La décision devient alors plus complexe, car le cahier des charges peut appeler à reproduire certains comportements de la culture-source et parallèlement à en adapter d'autres aux conventions de la culture-cible - et cela qu'il s'agisse de traduction documentaire ou instrumentale. Le troisième échelon fait intervenir la langue. Certes, nous pouvons dans la plupart des cas nous attendre à ce que la traduction s'aligne sur les normes du système formé par la langue-cible. Certains cas peuvent néanmoins nécessiter de reproduire les normes de la langue-source, par exemple pour réaliser une traduction interlinéaire à des fins linguistiques. Les deux derniers niveaux supposent enfin de dissiper ce qui reste de doute, en prenant d'abord en compte les restrictions d'ordre contextuel et, in fine, les éventuelles préférences personnelles du traducteur.

\section{ABSTRACT}

There are no rules for translation. Translation is a decision-making process, and each decision point involves uncertainty. In the following article, I would like to show how, from a skopos-theoretical perspective, a top-down procedure can at least reduce uncertainty to some degree. The top level is that of the translation brief, which determines the choice of translation type and form. This is a binary decision. A documentary translation usually "documents" the pragmatics of the source text, whereas an instrumental translation gets a pragmatics of its own, for example with regard to deixis. At the next level, the translator has to deal with cultural norms and conventions. Here, the decision becomes more complex because the brief may require the reproduction of some source-culture behaviours and the adaptation of others to target-culture conventions, both in documentary and instrumental translations. The next level is that of language. We may safely assume that most translations are expected to conform to the norms of the target-language system, but there may be cases where source-language norms have to be reproduced, for example in an interlinear translation for linguistic purposes. At the last two levels, the remaining doubts have to be resolved first in line with contextual restrictions and, ultimately, the translator's personal preferences, if necessary.

\section{MOTS-CLÉS/KEYWORDS}

théorie fonctionnaliste, cahier des charges, procédure descendante, typologie des traductions, conventions skopos theory, translation brief, top-down procedure, translation typology, conventions 
The highest rule of a theory of translational action is the "skopos rule": any action is determined by its purpose, i.e. it is a function of its purpose or skopos. (Reiß and Vermeer 1984/2013: 90)

\section{Introduction}

When I was trained as a translator, the question "How should $x y z$ be translated?" was usually answered by "It depends...," and then one teacher might add "... on the text type," another one, "on the availability of a (potentially) equivalent structure or word or expression or sentence in the target language," and yet another one "... on the context." Students learned to conform to these uncertain guidelines as best they could in order to get a good mark and pass the exam. After graduating, they had to deal with commissioners or translation agencies who did not even specify on what it depended but demanded "just a translation" - which added to their uncertainty.

From a skopos-theoretical perspective, these uncertainties seem to belong to a distant past, because now we know that "any action is determined by its skopos" (Reiß and Vermeer 1984/2013: 90), and if translating is an action, that is, a purposeful activity, it is governed by its skopos, too, and this is said to be a "rule," that is, a certainty. But what is the skopos of a particular translation, and how, or by whom, is it defined? This is where uncertainties may creep back into the translation process.

In the following paper, I want to show how a top-down approach may overcome these uncertainties at least to some degree. To illustrate my points, I am drawing on a small corpus of examples taken from the following texts: Christiane Olivier's Les enfants de Jocaste: L'empreinte de la mère (1980), ${ }^{1}$ its English translation Jocasta's Children: The Imprint of the Mother, by George Craig (1989), ${ }^{2}$ and its German translation Jokastes Kinder: Die Psyche der Frau im Schatten der Mutter, by Siegfried Reinke (1989). ${ }^{3}$

\section{The translation process from a functional perspective}

From a skopos-theoretical or functional perspective, the translation process is initiated by a person who needs a translation of a particular text and commissions a translator to produce it. In some way or other, the commissioner issues a translation brief, which may be quite specific at times but is usually rather vague. "Can you please translate this text, I need it tomorrow!" This brief does not mention the source or target language (because the client has hired a specialist for English-French translation), nor does it specify for which purpose and what audience it is intended, whether it will be published, what the medium will be, etc. except the deadline: tomorrow. This means that the translator has to "interpret" this brief to find out what it means for the actual translation process. Maybe it would be convenient to ask the commissioner for more details - commissioners are usually not experts in translation, how can they know what a translator needs to know about the target "situation" in order to get an idea of what the target text should be like? In any case, the result of this interpretation of the brief will be a "target-text profile."

In a next step, the target-text profile will be compared with the material offered by the source text. Is the task feasible at all? If so, is it feasible in such a short time? Let us assume it is feasible. This means that the translator has to make up a strategy: 
how can the aim (the skopos) be achieved as efficiently as possible? This strategy is going to be the overall guideline for the process of target-text production, in which the translation problems have to be solved in line with the skopos. Finally, the completed target text is compared with the requirements of the translation brief for quality control. If it fulfills these requirements, it will be an "adequate" translation and can be handed over to the commissioner.

This process is not a closed circle but a "loop" that includes all sorts of recursive smaller loops for research and documentation and for corrections or revisions (see the "looping model" in Nord 1991/2005: 39). Levý compares this process with a strategic game in which the translator has to cope with what "complete information" means at a given moment:

[...] since the process of translating has the form of a GAME WITH COMPLETE INFORMATION - a game in which every succeeding move is influenced by the knowledge of previous decisions and by the situation which resulted from them (e.g., chess, but not card games) (Levý 1967: 1172).

Uncertainty can occur in all phases of the translation process: in the interpretation of the translation brief (especially when it is unclear or very complex), in sourcetext analysis, comprehension and interpretation, in the planning of the transfer strategy, in target-text production, in quality control and at all levels of language and culture.

There may be different reasons for uncertainty. In translator training, uncertainty is often due to a lack of proficiency with regard to source and target languages and cultures, domain and terminological knowledge or regarding transfer techniques. This kind of uncertainty can be reduced by making sure that the degree of difficulty of the translation task is adequate to the students' level of proficiency (Nord 1991/2005: 188). Tasks that are too difficult will produce too much uncertainty for the student to cope with.

In translation practice, uncertainty is more often caused by source-text vagueness or defects or by insufficient translation competence. This kind of uncertainty can be reduced by a functional top-down approach, which we are suggesting in this paper.

\section{A top-down approach to deal with uncertainty}

In this section we will look at each level of the process, describing the reasons for uncertainty and the possibilities of dealing with doubt.

\subsection{Uncertainty and the brief}

As we have explained above, the translation brief (explicitly or implicitly) provides information about the situation for which the target text is needed: intended audience, medium, time and place of reception, and the intended communicative function(s). The interpretation of the brief enables the translator to decide what the target text should look like and what kind of macro-strategy is needed to produce a text which conforms to the target-text profile. Here, a functional translation typology may be of help to resolve uncertainty. 
Throughout the history of translation, translators have found that the first choice they have to make is between one of two translation types. Cicero, Jerome, Luther, Schleiermacher, Nida and others therefore made a basic distinction between sourceoriented and target-oriented translations (Nord 1997: 4-5), and in accordance with their respective situation and translation activities, each of them declared one to be "translation in the strict sense." From a functional perspective, both options can be legitimate depending on the purpose or skopos of the target text.

In my typology (Nord 1997: 45-52), the two basic types are called documentary and instrumental translation. A documentary translation is source-oriented. It "documents" a communicative interaction or any of its aspects in which a sourceculture sender communicates with a source-culture recipient under source-culture conditions. Depending on the focus of documentation, we can distinguish various forms of documentary translation. An interlinear translation focuses on the sourcelanguage system, which is reproduced for linguistic purposes, a literal translation reproduces the source-text form at word level, a philological translation reproduces form and content of the source text, adding information in paratexts wherever necessary, and an exoticizing translation tries to reproduce form, content and situation of the source text emphasizing cultural otherness.

An instrumental translation serves as an instrument for communication in the target culture which uses the "material" provided by the source text but takes the form of a target-culture text. Here, an equifunctional translation would be intended to achieve the same communicative functions for a target-culture audience which the source text achieves or achieved for a source-culture audience. A heterofunctional translation may change the hierarchy of functions for which the source text was intended (for example because one of the functions, like that of a satire, cannot be achieved with the target audience), and a homologous translation tries to produce a text whose (usually literary) status is similar to that of the source text.

This specification of translation type and form can reduce uncertainty at the level of the translation brief. For this purpose, trainee translators should be acquainted with translation briefs from the very beginning of their training. Practitioners, in turn, should try to retrieve as much information as possible about the target-text situation, for example by contacting the client, negotiating conditions, etc. And they should make up their minds before embarking on a translation project what the appropriate type and form of translation will be in each case. Maybe they should even tell their audience in a foreword what their overall translation strategy was.

In the case of our corpus text, the translators interpreted their source text in a similar way but came to different conclusions, as we shall see in the discussion of the examples below. What they write in their respective forewords could be regarded as a "self-imposed brief."

The intensely personal, first-hand nature of the arguing puts it closer to eager, even impatient speech than to systematic exposition. But then that mode itself, for her, is bound up with the ideology whose falsity she wants to show. The translator must try, then, to follow her in her changes of tempo and tone, her preference for questions over statements, her yokings of private and public, her inventions and her repetitions. It seems overwhelmingly worthwhile. (Craig in Olivier 1989a: viii)

Christiane Oliviers Material kommt aus der Sprache, in der sich das Denken und Fühlen des Individuums wie der Gesamtgesellschaft ausdrückt. Ein Gedankenaustausch 
mit der Autorin bestätigt diese Sicht. Das vorliegende Buch ist daher reich an Metaphern und Wortspielen, die möglichst wortgetreu ins Deutsche übertragen wurden. Wenn dies erforderlich schien, wurde versucht, den Sinn durch Anmerkungen zu verdeutlichen.

[Christiane Olivier's material is language, which expresses the thoughts and the feelings of both the individual and the entire society. A conversation with the author confirms this view. Therefore, the present book is rich in metaphors and puns, which were rendered as literally as possible. Wherever necessary, we tried to explain the meaning in notes.] (Reinke in Olivier 1989b: 179; our translation)

From these few lines it becomes already clear that the English translator aimed at an instrumental translation whereas the German translator opted for a documentary one.

\subsection{Uncertainty and pragmatics}

As a general rule, documentary translations reproduce the pragmatics of the sourcetext situation. Target-text readers are expected to put themselves into the source-text readers' shoes, drawing their own conclusions with regard to what the text may mean for them. This means that it is the target audience's task to "transfer" any deictic references to the source culture or language. Paratexts (foreword, notes, glossaries, etc.) are sometimes used to bridge the pragmatic gap between source-text and targettext situations in case of large temporal, spatial or cultural distances (for example in philological translations). Exoticizing translations may bridge the pragmatic gap by using language and style which is accessible to a target-cultural audience.

Instrumental translations are adjusted to the new pragmatics of the target situation. Here, it is the translator who accomplishes the transfer, making it easier for the target audience to relate to the text content.

(1) Dans quelle nouvelle littérature, dans quelles étranges bandes dessinées (si ce n’est celles de C. Brétecher) voyons-nous le père «paternant» son enfant?

(Olivier 1980: 55)

(a) Where are the new novels, where are the way-out cartoons (apart maybe from those of Claire Brétecher) that show us a father 'mothering' his child?

(Olivier 1989a: 34; translated by George Craig)

(b) Wo in der neuen Literatur, in welchen noch so ausgefallenen Comics (außer in denen von Claire Brétecher) sehen wir den Vater beim „Bevatern“ seines Kindes?

(Olivier 1989b: 49; translated by Siegfried Reinke)

Example 1 shows that both translators assume their audiences to be familiar with the French feminist cartoonist Claire Bretécher ${ }^{4}$ and her work, at least if the first name is spelled out. Since the time lag between the original and the two translations is quite considerable, an explicitation like "the French feminist" might have been appropriate in Craig's instrumental-equifunctional translation, whereas in Reinke's documentary-philological translation this is the only reference to the source culture which is not explained in a footnote.

Moreover, the translation of paternant by the word creation Bevatern (in analogy to Bemuttern, mothering), however equivalent at the morphological level, does not work in this context. The German verb bemuttern has a slightly ironical connotation and is used of a mother who treats her adult son like a child. 
Olivier refers to a cartoon from Les Frustrés $4,{ }^{5}$ where a father changes the baby's nappies and bottle-feeds it (Figure 1). Therefore, a paraphrase referring to exactly this content would have been more appropriate for readers who are not familiar with Bretécher's cartoon, which is rather likely since Les Frustrés 4 was published in German in 1989 and English translations of Brétecher's cartoons were not available until 1992.

\section{FIGURE 1}

Le père "paternant» son enfant (Bretécher 1979/1989, no pagination)

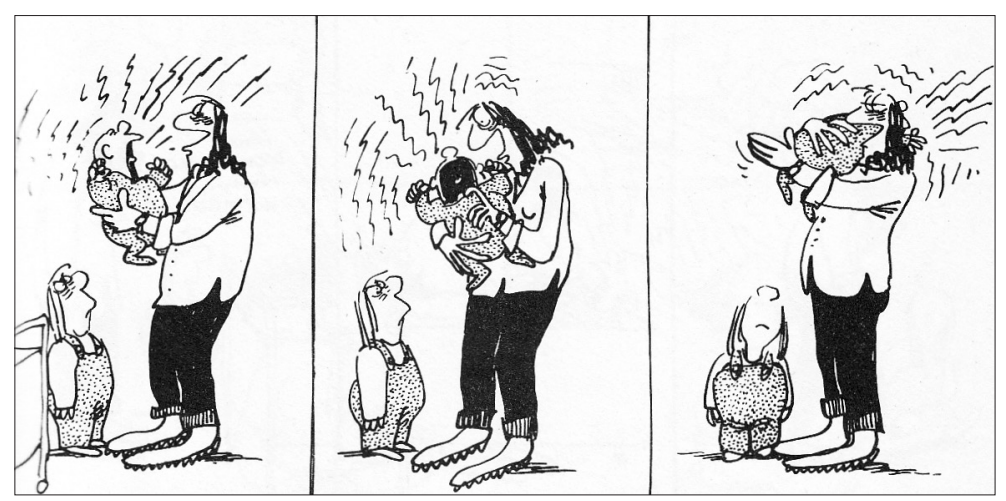

(2) Le père, dans nos pays latins, n'est pas destiné à s'occuper du «petit», que ce soit le sien ou celui des autres.

(Olivier 1980: 55)

(a) In 'Latin' countries like France, the father has not been brought up to look after the baby - his own or anybody else's.

(Olivier 1989a: 54; translated by George Craig)

(b) Der Vater ist in unseren romanischen Ländern* nicht dazu bestimmt, sich um das „Kleine“ zu kümmern, sei es das eigene oder das der anderen.

Translator's note:

${ }^{*}$ Das dürfte auch auf andere Länder zutreffen (Anm. d. Ü.)

(Olivier 1989b: 49; translated by Siegfried Reinke)

In line with the selected translation types and form, the English translator explicitates the reference to France, which reveals Olivier's critical attitude towards her own country, whereas the German translator translates literally, producing an incoherent text for German readers, who may be puzzled by the reference to "our Roman countries." The translator's note is simply redundant, because any reader from another country, where the situation is similar, will relate the author's statement to his/her own situation. This tendency to patronize the readers is not in line with a documentary translation.

\subsection{Uncertainty and culture}

At the level of pragmatics, the choice is binary. Documentary translations reproduce source-text pragmatics, whereas instrumental translations adapt to the new target situation. At the level of culture, which we understand as the total setting of norms 
and conventions for behaviour, the choice is not such a binary one. Documentary translations may reproduce some source-culture norms and conventions and adapt others, and the same is true for instrumental translations. There are even norms and conventions for translation or rather, for the solution of certain translation problems. In some cultures, for example, proper names are usually reproduced as they appear in the source text, in others, they are adapted, wherever possible, to target-language morphology, phonology or spelling. Even if the form is not changed, as, for example, in some translations of Alice in Wonderland, the pronunciation may be different: Alice (with the stress on the first syllable) is Alice (with the stress on the last syllable) in the French and the German translation and Alice (pronounced Alitche) in the Italian version. In the Spanish translation she is called Alicia, and in the Finnish translation Liisa.

Example 3 shows one of the few cases where the English translator does not follow his usual strategy of adapting behaviour to target-culture conventions (parallel texts found in the Internet refer to the [distinguished, conservative] French historian Pierre Chaunu). But the use of the title Mr. is at least not unusual in English. In German, however, references to persons never use the generic title Herr (let alone Monsieur) because this produces a clearly depreciative or ironical tone, particularly when used with the indefinite article. Parallel German texts refer to der [bekannte] französische Historiker Pierre Chaunu.

(3) Que demande M. P. Chaunu, professeur d'histoire moderne, dans les colonnes d'un article publié dans Marie-France en janvier 1978, sous la rubrique: «Sommes-nous trop ou pas assez nombreux?»

(Olivier 1980: 187)

(a) Let us look at the demands put forward by Mr P. Chaunu, a professor of modern history, in an article published in Marie-France in January 1978, under the heading: 'Are there too many of us or too few?'

(Olivier 1989a: 143; translated by George Craig)

(b) Was fordert ein Monsieur P. Chaunu, Professor für moderne Geschichte, unter der Überschrift: „Sind wir zu viele, oder sind wir nicht zahlreich genug?“ in den Spalten eines in Marie-France* zu jener Zeit veröffentlichten Artikels?

Translator's note:

^Französische Frauenzeitschrift (Anm. d. Ü.)

(Olivier 1989b: 170; translated by Siegfried Reinke)

Even in a documentary translation the form of the reference to a person would normally be adapted to target-culture conventions, unless it is precisely this convention which is supposed to be "documented" in the translation. The note explaining that Marie-France is a French women's magazine is again underestimating the reader's text-reception capacities and world knowledge and should be dealt with at the level of pragmatics. Even for readers who are not familiar with this magazine, the context is sufficiently clear (an article published [...], together with the name Marie-France, points to a French women's magazine).

Coming back to culture-specific conventions, we may also point out that it is a style convention in French to read something dans les colonnes of an article (even if it is not printed in columns), whereas it is absolutely uncommon in German to mention die Spalten of an article. Having chosen a documentary translation does not 
mean that any stylistic norms and conventions of the source culture have to be reproduced in the target text.

\subsection{Uncertainty and the text}

According to skopos theory, a text is an offer of information, from which recipients "pick" the items they can (or want to) process (see Reiß and Vermeer 1984/2013: 61). The translator is a recipient of the source-culture offer of information. When translating from the foreign into the own language and culture, the translator does not even belong to the audience addressed by the source-text author. Therefore, there may be a great deal of uncertainty regarding the interpretation of the source text.

The only way for translators to know what to "pick" for the target-culture audience is to put themselves in their shoes and offer them those items of the source-text offer of information which will be appropriate to achieve the functions required by the brief. But there cannot be any certainty that the target audience will actually use the target text for the intended functions.

(4) Après tout, Freud n'a-t-il pas découvert les règles sous-jacentes à une foule de jeux dont nous usions jusque-là en toute innocence? Celui de la bobine n'est-il pas un des plus connus (l'enfant symbolise l'absence de la mère au moyen d'un objet qu'il envoie au loin, pour le récupérer l'instant d'après) ...?

(Olivier 1980: 47-48)

(a) After all, did Freud not discover the rules underlying many of the games we had up till then played in all innocence? Among the best-known games do we not find the one with the cotton reel (in which the child invents a symbolic representation of its mother's absence by an object which it throws away, then immediately brings back)?

(Olivier 1989a: 29-30; translated by George Craig)

(b) Hat nicht schließlich Freud selbst die unterschwelligen Regeln einer Vielzahl von Spielen aufgedeckt, die wir bis dahin in aller Unschuld gespielt haben? Ist nicht eines der bekanntesten das Diabolo-Spiel* (das Kind symbolisiert die Abwesenheit der Mutter durch ein Objekt, das es von sich entfernt, um es im nächsten Moment zurückzuholen)?

Translator's note:

${ }^{\star}$ Anm. d. Ü.: (ital. von diavolo = Teufel) Kinderspielzeug, Doppelkreisel, der auf einer an zwei Stäben befestigten Schnur rotiert, in die Höhe geworfen, wieder auf der Schnur aufgefangen wird.

(Olivier 1989b: 44; translated by Siegfried Reinke)

Example 4 is particularly interesting with regard to text interpretation. It seems incoherent that the game with the cotton reel is said to be among the best-known games if nobody has ever heard about it, let alone played it. This was probably the reason why the German translator looked for a well-known game in the German-speaking world (although this procedure is not compatible with his choice of translation type and form). The problem with Diabolo is that the explanation given by Olivier does not fit the game (not to mention the fact that the etymology given in the note is incorrect: diabolo is derived from the Greek word diaballein, to throw away, and not from the Italian word diavolo, devil). A diabolo is a juggling device consisting of an axle and two cups or discs, which are spun using a string attached to two hand sticks. 
If we want to substitute the cotton reel for a more common toy, a yo-yo would probably be more appropriate to fit Olivier's interpretation.

However, this is a case in which specific domain knowledge is needed to interpret the text correctly. Olivier is not referring to one of the best-known games in general but to one of the best-known of Freud's examples for an innocent children's game. In his essay Beyond the Pleasure Principle (1922), Freud is actually referring to a cotton reel, using the German word Garnrolle. The problem we have to solve here, at least in the case of the German translation, is a reference to the target culture, which should use a back-translation to the original Freudian term. In this case, the uncertainty which led to the mistranslation was caused by a lack of specific domain knowledge. Of course, in the 1980s it would have meant a lot of research in Freud's collected works to find the particular essay in which he describes how his 18-months-old grandson played with a wooden reel. Today, with the help of the Internet, just a few clicks led to the original German text and the English translation, which refers to "a wooden reel with a piece of string wound round it."

Occasionally, however, this well-behaved child evinced the troublesome habit of flinging into the corner of the room or under the bed all the little things he could lay his hands on, so that to gather up his toys was often no light task. He accompanied this by an expression of interest and gratification, emitting a loud long-drawn-out 'o-o-o-oh' which in the judgement of the mother (one that coincided with my own) was not an interjection but meant 'go away' (fort). I saw at last that this was a game, and that the child used all his toys only to play 'being gone' (fortsein) with them. One day I made an observation that confirmed my view. The child had a wooden reel with a piece of string wound round it. It never occurred to him, for example, to drag this after him on the floor and so play horse and cart with it, but he kept throwing it with considerable skill, held by the string, over the side of his little draped cot, so that the reel disappeared into it, then said his significant 'o-o-o-oh' and drew the reel by the string out of the cot again, greeting its reappearance with a joyful ' $\mathrm{D} a$ ' (there). This was therefore the complete game, disappearance and return, the first act being the only one generally observed by the onlookers, and the one untiringly repeated by the child as a game for its own sake, although the greater pleasure unquestionably attached to the second act. (Freud 1922/2010, chapter II)

The example also proves how important a top-down procedure is. From the overall situation (author, time, intentions, etc.) we know that Christiane Olivier's psychology is anti-Freudian. She is absolutely familiar with Freud's works and often quotes, directly or indirectly, from his writings. This knowledge guides our interpretation of the passage cited in Example 4, which otherwise would seem rather incoherent, producing a high degree of uncertainty. The German translator usually quotes the German titles of Freud's writings, so he must have been familiar with the texts. However, since Jenseits des Lustprinzips (Beyond the Pleasure Principle) was not cited explicitly, he may have missed precisely this text.

\subsection{Uncertainty and the phrase}

Normally, professional (functional) translators do not translate isolated phrases but phrases-in-context, and contexts reduce uncertainty regarding the interpretation of phrases, as we have seen in Example 4. Metalinguistic references to phrases, however, may require a close rendering even of a phrase. If the target-language does not provide 
a similar or equivalent phrase, a shift may be necessary. The necessity of a shift is bound to produce uncertainty.

(5) La femme «tombe» enceinte, vous connaissez l'expression. Comme si brutalement elle avait un accident, quelque chose qu'elle n'aurait pas prévu et qui la ferait trébucher.

(Olivier 1980: 60)

(a) The women 'gets' pregnant, in the phrase everyone knows. As if with brutal suddenness she had contracted something by accident, something that would lay her low.

(Olivier 1989a: 39; translated by George Craig)

(b) Die Frau „gerät in Umstände“*. Sie kennen den Ausdruck. Als ob sie ganz plötzlich einen Unfall hätte, etwas das sie nicht hätte voraussehen können, etwas das sie „stolpern ließ“.

Translator's note:

${ }^{\star}$ Im frz. Original „La femme ,tombe enceinte....; dadurch schließt sich der folgende Gedanke eines Unfalls („accident“) im Original logischer an.

(Olivier 1989b: 54; translated by Siegfried Reinke)

In an ironic tone, the author comments on the French phrase tomber enceinte, literally to fall pregnant, to illustrate the ideology hidden in apparently innocent phrases. Both translators are in doubt how to solve this translation problem given that neither English nor German use similar phrases to describe pregnancy. In line with his choice of translation type and form, Craig uses the normal English expression to get pregnant. The problem is that this is not a "phrase" in the strict sense of the term and that it does not, at least in my mind, evoke the picture of something that "lays the woman low." According to his usual documentary strategy, Reinke should have provided a literal translation of the French phrase, adding something like "as we say in French." However, he creates a new German "phrase," in Umstände geraten, literally to come into circumstances, in analogy to the euphemism in anderen Umständen sein, to be in other circumstances, which is neither a documentary-literal translation nor an adaptation that would lead to an instrumental translation. The following sentence Sie kennen den Ausdruck, you know the expression, is incoherent for the readers because they cannot know an expression which does not exist in German. In the note, he refers to the French phrase, without translating it. Obviously, he forgot the only certainty about the audience he is addressing: they do not know French.

In a consistently instrumental translation, a German translator would have to look for a shift, since German does not have a phrase with similar connotations to express pregnancy. A thesaurus is a useful tool to reduce uncertainty in this respect. In the semantic field of pregnancy or childbirth, for example, German has the verb niederkommen, literally: to come down, a slightly obsolescent term for to give birth. Of course, using this verb (it is not a phrase either) would require some more shifts in the passage.

Die Frau „kommt nieder“, sagt man. Ist Ihnen schon einmal aufgefallen, dass das so klingt, als hätte sie plötzlich einen Unfall, bei dem etwas Unerwartetes auf sie herabfällt, das sie zu Boden wirft? 
[The women "comes down," it is said. Have you ever realized that this sounds as if she had an accident, in which something unexpected falls down on her that throws her on the ground?]

(Our translation)

\subsection{Uncertainty and the word}

At the word level, uncertainties arise from polysemy, cognates (or "false friends"), lack of target-language equivalence, etc. Usually, this kind of uncertainty will be reduced or even solved by (linguistic, cultural or pragmatic) context information, unless the translator aims at concordance at the word level, as some Bible translations do. The German translator seems to use such a strategy, for example with the word discours, which is used in different contexts and with different meanings by the author. The first few lines of the author's foreword illustrate Olivier's position between the extremes.

(6) Il y a le discours analytique: recherché, compliqué, étudié pour vous écarter, vous semer, vous éberluer vous qui n'êtes pas analystes... Il y a le discours féministe: discours coloré, imagé, sexué, fait pour que vous entriez, compreniez, même si vous n'êtes pas féministe, d'autant que vous n'êtes pas féministe... Et il y a ceux qui ne se reconnaissent ni dans l'un ni dans l'autre parce que, de toute façon, ils refusent d'être extrémistes. Me tenir entre ces deux discours, ne pas m'isoler en adoptant le premier, ne pas vous submerger en parlant le second. Parler le langage du milieu, celui que ne met de côté ni l'affect ni l'intellect. Entre femme et analyste, c'est-à-dire porter les deux extrêmes, garder ensemble l'émoi et le verbe, refuser d'être ou plus femme ou plus analyste, refuser de me diviser ou de me spécialiser.

(Olivier 1980: 5, Avant-propos)

(a) Psychoanalysis has its language: sophisticated, complicated, designed to drive away any of you who are not analysts, to throw you off the track, blind you with science. Feminism has its language: high in colour and imagery, sexualized, made to allow you in, to let you understand, even if you're not a feminist, most of all if you're not a feminist. Then there are those who don't feel at home in either because in any event they refuse to be extremists. Must stay somewhere between these two languages; not cut myself off from you by taking up the first, not swamp you by talking the second. Must talk instead the language of the centre, which leaves out neither emotion nor intellect. Must be woman and analyst, that is, keep up the two extremes, keep together the orderedness and the disorder of feeling, refuse to be either more woman or more analyst, refuse to split or specialize.

(Olivier 1989a: ix, Introduction; translated by George Craig)

(b) Es gibt den analytischen Diskurs: spitzfindig, gekünstelt, kompliziert, um Sie, den Nicht-Analytiker, zu verblüffen und auf Distanz zu halten... Es gibt den feministischen Diskurs: farbig, bildhaft, sexualisiert, dazu da, um Sie einzubeziehen und verstehen zu lassen, selbst wenn Sie kein(e) Feminist(in) sind - oder gerade weil Sie es nicht sind... Und es gibt jene, die sich weder in dem einen noch in dem anderen wiedererkennen, weil sie auf jeden Fall extreme Positionen ablehnen. Für mich ist die Mitte entscheidend. Ich will mich nicht isolieren, wenn ich mich in den ersten Diskurs begebe, und Sie nicht überschwemmen, wenn ich den zweiten verwende. Ich möchte versuchen, die Sprache der Mitte zu sprechen, die sowohl das Gefühl als auch den Intellekt berücksichtigt: Frau und Analytikerin zu sein heißt, beide Extreme in sich zu tragen, sich nicht teilen zu lassen.

(Olivier 1989b: 9, Vorwort; translated by Siegfried Reinke) 
A brief analysis of the wider context reveals that Olivier uses discours and langage as synonyms and that she is not speaking as a linguist. In German, Diskurs is used mainly as a linguistic term, similar to discourse in English. Therefore, the German translation is contradictory to the author's own attitude. It illustrates, again, that being "faithful to the word" often entails "unfaithfulness to the sense." This is also shown by the following two examples. Example 7 is the title of a short chapter following the author's foreword and presenting a loose sequence of quotes by Sigmund Freud, Hélène Cixous, Jacques Lacan and others about the woman.

(7) Discours imaginaire

(Olivier 1980: 7)

(a) Voices off

(b) Imaginärer Diskurs

(Olivier 1989a: x; translated by George Craig i)

(Olivier 1989b: 9; translated by Siegfried Reinke)

(8) [...] le premier discours, car avant le transférentiel il y eut le Transmaternel.

(Olivier 1980: 6)

(a) [...] the earliest language of all. For, long before the transferential, there was the transmaternal.

(Olivier 1989a: viii; translated by George Craig)

(b) [...] ist es notwendig, bis zum allerersten Diskurs zurückzugehen, denn vor der Übertragung gab es das `Transmütterliche $\iota^{*}$, das, was von der Mutter zu uns kommt.

Translator's note:

*Wortschöpfung der Autorin: im Original „Transmaternel“, in Anlehnung an „transférentiel“, die später einsetzende Übertragung (Anm.d.Ü.).

(Olivier 1989b: 8; translated by Siegfried Reinke)

In Example 7, discours refers to a virtual debate between the quoted authors, whereas in Example 8 the same word describes the first bond or exchange between the mother and the unborn child. In neither case does Diskurs make any sense whatsoever in German.

At the word level, even morphology may be a cause for uncertainty. In French and English, creating a neologism from a Latin root and a Latin prefix works fine, in German, however, a Latin prefix (trans-) cannot be combined with a Germanic root (mütterlich). Depending on the addressed audience, a Latinism like transmaternell might be appropriate. This has to be decided at the level of pragmatics.

\section{Conclusions}

Every translation process involves uncertainty, and a functionalist approach does not (and cannot) promise a process that is free of doubt. We have tried to show, however, that a procedure, which starts at the level of the translation brief and then goes down step by step to the levels of pragmatics, culture, language, text and even the word, can narrow down the possibilities of choice, thus reducing uncertainty. The translation brief defines the conditions for the choice of translation type and form, and according to the translation type, the pragmatics of the source text are either maintained (and documented) in the target text or replaced by the pragmatics of the "new" 
situation, in which the target text is supposed to "function" as a rather independent instrument for communication between target-culture partners. At the level of culture, in the sense of behavior norms and conventions, the conditions are not as straightforward as they are with regard to pragmatics. There may be source-culture norms and conventions which can also work in the target culture, whereas others would cause misunderstandings or at least disconcertment, making comprehension difficult or impossible. At the level of language, we may safely assume that most translations are expected to conform to target-language norms, but this is by no means a rule - in any event, the translator has to make sure whether certain passages, such as metalinguistic or metacommunicative comments, require a more sourcelanguage oriented choice. After proceeding down to the levels of phrase and word, or even morphology, there may still be some occasions where uncertainty arises. If two or more lexical units would be appropriate to fulfill the demands of the higher ranks, context restrictions or, eventually, the translator's personal stylistic or idiolectal preferences may be used to resolve these last doubts.

In the practice of professional translation, such a top-down procedure may seem too time-consuming to allow for efficiency and meeting tight deadlines. The point is, however, if it is practiced from the very beginning of the training, translators will internalize this way of dealing with doubt, thus gaining a justified degree of certainty.

\section{NOTES}

1. Olivier, Christiane (1980): Les enfants de Jocaste: L'empreinte de la mère. Paris: Éditions Denoël.

2. Olivier, Christiane (1989a): Jocasta's Children: The Imprint of the Mother. (Translated by George Craig). London/New York: Routledge.

3. Olivier, Christiane (1989b): Jokastes Kinder: Die Psyche der Frau im Schatten der Mutter. (Translated by Siegfried ReInKe). Munich: dtv.

4. The name is misspelled as Brétecher in all three texts of our corpus.

5. Bretécher, Claire (1979/1989): Les Frustrés 4. Paris: Claire Bretécher.

\section{REFERENCES}

Freud, Sigmund (1922/2010): Beyond the Pleasure Principle. (Translated by C. J. M. НubBack). Bartleby.com. Visited 20 April 2015, <http://www.bartleby.com/272/>.

LevÝ, Jiři (1967): Translation as a Decision Process. In: To Honor Roman Jakobson: Essays on the Occasion of his Seventieth Birthday, 11 October 1966. Vol. I-III. Janua Linguarum Series Maior, 31, 32, 33. The Hague/Paris: Mouton.

NoRD, Christiane (1991/2005): Text Analysis in Translation. A Model for Translation-Oriented Text Analysis. (Translated by Christiane Nord and Penelope Sparrow), $2^{\text {nd }}$ ed. Amsterdam: Rodopi.

Nord, Christiane (1997): Translating as a Purposeful Activity. Functionalist Approaches Explained. Manchester: St Jerome.

Reiss, Katharina and Vermeer, Hans J. (1984/2013): Towards a General Theory of Translational Action. Skopos Theory Explained. (Translated by Christiane NorD, English reviewed by Marina Dudenhöfer). Manchester: St Jerome. 